\title{
Discovery of a population of Spondylurus powelli (Squamata: Mabuyidae) on Île Tintamarre (Saint-Martin, French Antilles) and comments on relation- ships among skinks of the Anguilla Bank
}

\author{
Olivier Lorvelec ${ }^{1,2, *}$, Nicolas Barré ${ }^{2}$, Julien Chalifour ${ }^{3}$, Alexandre Teynié ${ }^{4}$, Benoît Pisanu ${ }^{5}$, and
}

\section{S. Blair Hedges ${ }^{6}$}

'ESE (Écologie et Santé des Écosystèmes), INRA, Agrocampus Ouest, 65 Rue de Saint-Brieuc, 35042 Rennes, France.

${ }^{2}$ AEVA (Association pour l'Etude et la protection des Vertébrés et végétaux des petites Antilles), 97170 Petit-Bourg, Guadeloupe, France. ${ }^{3}$ Association de Gestion de la RNNSM (Réserve Naturelle Nationale de Saint-Martin), Résidence les Acacias, Anse Marcel, 97150 Saint-Martin, France.

${ }^{4}$ EPIA (Epidémiologie des Maladies Animales et Zoonotiques), INRA, VetAgro Sup, 63122 Saint-Genès-Champanelle, France.

${ }_{5}^{5}$ UMS 2006 Patrimoine Naturel, MNHN, AFB, CNRS, Maison Buffon, CP 41, 36 Rue Geoffroy Saint-Hilaire, 75231 Paris Cedex 05, France.

${ }^{6}$ Center for Biodiversity, Temple University (502 SERC), 1925 N. 12th Street, Philadelphia, PA 19122, USA.

${ }^{*}$ Corresponding author (olivier.lorvelec@inra.fr)

Edited by: Robert Powell. Date of publication: 6 July 2017.

Citation: Lorvelec O, Barré N, Chalifour J, Teynié A, Pisanu B, Hedges SB. 2017. Discovery of a population of Spondylurus powelli (Squamata: Mabuyidae) on Île Tintamarre (Saint-Martin, French Antilles) and comments on relationships among skinks of the Anguilla Bank. Caribbean Herpetology, 59, 1-8.

\begin{abstract}
In March 2013, we discovered a population of skinks on Île Tintamarre located northeast of Saint-Martin. All individuals observed in 2013 and 2014 were found in a network of dry stone walls. Genetic and morphological analyses unambiguously show that this population belongs to Spondylurus powelli, which also lives on Anguilla and Saint-Barthélemy, and not to S. martinae, the species of adjacent Saint-Martin. This unexpected pattern of distribution is similar to that of at least one other species of squamate reptile and further supports the distinction of these two recently described species of skinks. The population size is estimated at only 40-50 adult individuals. Threats are specified and we recommend necessary measures for the conservation of this population.
\end{abstract}

Keywords: Caribbean, island, lizard, Spondylurus, systematics, biogeography, threats, conservation.

In March 2013, we discovered a population of skinks on Île Tintamarre. This islet belongs to the Anguilla Bank in the northern Lesser Antilles. This group of islands, separated by a relatively shallow seabed, was a single island during marine regressions linked to Quaternary glaciations. The Anguilla Bank (Fig. 1) comprises three main islands of Anguilla, Saint-Martin, and Saint-Barthélemy. The principal islets of Anguilla are Scrub Island, the Prickly Pear Cays, and Dog Island. Those of Saint-Martin (hereafter St. Martin) are Île Tintamarre (hereafter Tintamarre) and Îlet Pinel (hereafter Pinel). Those of Saint-Barthélemy (hereafter St. Barts) are La Tortue, Île Frégate, île Chevreau, and Île Fourchue.

Tintamarre $\left(1.20 \mathrm{~km}^{2}\right.$, Fig. 2$)$ is an uninhabited island located less than $3 \mathrm{~km}$ northeast of St. Martin (87 $\mathrm{km}^{2}$ ). The maximum elevation of Tintamarre is about $30 \mathrm{~m}$ in the north and northeast. Its west/east length and its north/south width, intersecting in the center of the island (18.11873, -62.98092), are $1.60 \mathrm{~km}$ and $0.67 \mathrm{~km}$, respectively. This island is particularly dry due to low precipitation and its porous limestone soil. Other than a lagoon and dune areas, the vegetation is dominated by a dry forest, thickets, and, on the eastern side, an aerohaline lawn. All of the vegetation is affected by grazing feral goats. Human activity is now limited in the interior of the island but tourism is relatively important on the beach and adjacent southwestern areas of the island. Tintamarre is part of the "Collectivité de Saint-Martin" (53 km²), a French overseas collectivity located on the northern side of St. Mar- 
tin. Sint Maarten $\left(34 \mathrm{~km}^{2}\right)$, an autonomous Dutch state, is located on the southern side of St. Martin. The whole of Tintamarre is classified as a natural area of ecological, faunal, and floristic interest (ZNIEFF Type I according to French legislation). The central portion of the island $\left(0.73 \mathrm{~km}^{2}, 61 \%\right.$ of the total) belongs to a private owner. Only the coastal zone $\left(0.47 \mathrm{~km}^{2}, 39 \%\right.$ of the total) belongs to the "Conservatoire du Littoral" (hereafter $\mathrm{CL}$ ) and is part

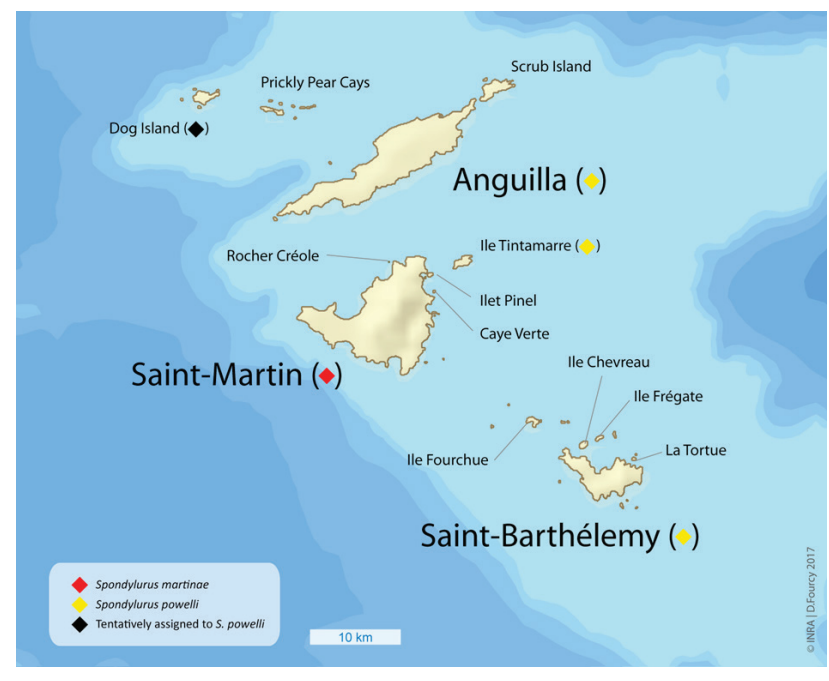

Figure 1. Distribution of skinks of the Anguilla Bank based on Hedges \& Conn (2012) and this paper. of the territory of the "Réserve Naturelle Nationale de Saint-Martin" (hereafter RNNSM).

Hedges \& Conn (2012) assigned seventeen species of skinks to the genus Spondylurus, including ten new species described in their work. The distribution of the genus ranges from the Turks and Caicos Islands (southeast of the Bahamas) through Jamaica, Hispaniola, and the Puerto Rican region (including Mona, Monito, the U.S. and British Virgin Islands) to the Anguilla Bank in the Lesser Antilles. The only skinks of the Anguilla Bank, S. martinae and S. powelli, were both newly described by Hedges \& Conn (2012). Spondylurus martinae, the St. Martin Skink, was described on the basis of two MCZ (Museum of Comparative Zoology, Cambridge) specimens collected on an unknown date but no later than 1966 and seven ANSP (Academy of Natural Sciences, Philadelphia) specimens probably collected between 1863 and 1877, all from the main island of St. Martin. In the case of the MCZ specimens, the original museum ledger indicates that they were collected by "G. A. Scamon" and donated to MCZ by Wagenaar Hummelinck, a Dutch marine biologist who was active in the middle of the $20^{\text {th }}$ Century. A search of the MCZ database for his other donations of material collected on St. Martin indicates actual collection dates in 1963. From this, we surmise that the two skinks from Little Bay were probably collected at approximately the same time ( 1963), shortly before being accessioned in 1966. Spondylurus powelli, the Anguilla Bank Skink, was described on the basis of ten specimens collected from 1963 to 2000 on Anguilla and six specimens collected in 1997, 2003, and at unknown dates on St. Barts. In the same work, the authors defined the martinae group, a species group including only these two species.

The aim of this paper is to specify habitat and size of the population on Tintamarre, and identify the species to which this population belongs. We also discuss how the discovery of a population of skinks on Tintamarre pertains to the biogeography of skinks of the Anguilla Bank. Finally, we provide some recommendations for conservation of the Tintamarre population.

\section{Materials and Methods}

The search for skinks required walking slowly and silently along paths, in the undergrowth, in open areas, or near small dry stone walls, while observing a few meters to the sides and ahead, or using binoculars. We focused attention on small and dry stone walls in good condition. We progressed along the sides of walls, or on the tops of walls ( $1.5 \mathrm{~m}$ high and width) when vegetation prevented us from passing on the side. Our visits were generally in the morning between 0730 and $1130 \mathrm{~h}$ in good weather conditions. Our movement was generally slower than one kilometer an hour. Wherever possible, each observation of a skink was associated with a GPS point, the date and time, the weather conditions, the sun exposure, the nature of the substrate on which the animal was found, the description of its habitat, and the possible presence of predators. Photographs were taken as often as possible. Three individuals of the Tintamarre skink population were sampled genetically. Sequences of three mitochondrial genes (12S rRNA, 16S rRNA, and cytochrome b) were obtained, following the methods detailed in Hedges \& Conn 
(2012), and deposited in GenBank (KY905146-KY905154). The morphological methods followed Hedges \& Conn (2012).

\section{Results}

Discovery of the population and its habitat. A survey of mammals introduced on the islands belonging to the RNNSM was carried out in March 2013 by the "Institut National de la Recherche Agronomique" (thereafter INRA) and the "Association de Gestion de la RNNSM". Tintamarre, Pinel, Caye Verte, and Rocher Créole were also investigated in order to seek potential skinks. No skink was observed on Pinel (four visits), Caye Verte (four visits), or Rocher Créole (one visit), the latter comprising a pair of tiny islands that do not provide a favorable habitat for skinks. Our experience acquired on Terre de Bas (Îles de la Petite Terre) and on La Désirade in Guadeloupe (Lorvelec 2011; Lorvelec et al. 2012, 2016; Schedwill et al. 2014; Métaireau et al. 2014; Hedges et al. 2016) had led us to expect to discover a population of skinks in the small dry stone walls of Tintamarre. During three days of prospecting, from 8 to 10 March, six people (including OL, JC, and BP) observed in total 10 skinks representing at least 8 different individuals (Lorvelec et al. 2013, 2016; Fig. 3 B). They were all found on dry, interconnected stone walls, without mortar and in good condition. These dry stone walls were constructed using large flat stones on each side; these were slightly inclined downward toward the middle of the wall and the space between was filled with smaller stones. No observations were made in other habitats of the island. The dry stones walls are in the west of Tintamarre (Fig. 2). The four largest are around 400 meters long (M1-4). From the edge of the cliff to the north, they extend towards the south for $70 \%$ of the width of the island. They are located in a dry forest to the north, which gradually gives way to thickets going southward. They are joined by a network of shorter dry stone walls to the south. The dry stone wall where the largest number of skinks was seen, i.e., 7 reports corresponding to at least 5 different individuals, is M2 (Fig. 2). All observations were made in the north-

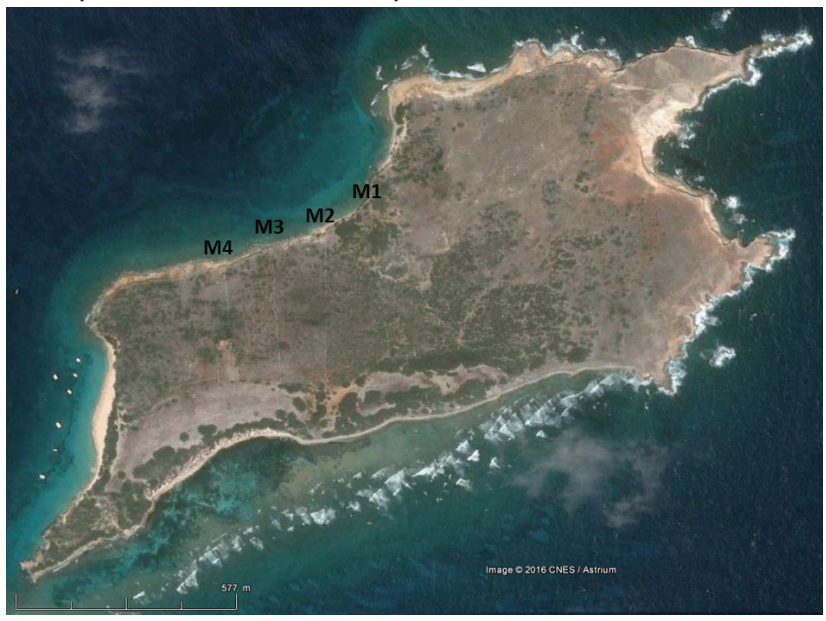

Figure 2. Tintamarre: Google Earth image taken on 2 February 2017 showing the main dry stone walls (M1-4) that provide important habitat for the skinks on the island. ern part of that wall (125 m of a total of $370 \mathrm{~m}$ ). The authors of the initial report (Lorvelec et al. 2013) tentatively assigned the skinks from Tintamarre to Spondylurus martinae. This initial report includes a photograph, which is also reproduced in Powell et al. (2015). In March 2013, OL, BP, and another person spent one day looking for skinks along two trails on the French side of St. Martin (Sentier des Froussards and Sentier du Pic Paradis) but failed to see any skinks.

In November 2014 a survey devoted to skinks was carried out on Tintamarre. The prospecting was spread over four days with a team of eight members (including OL, NB, JC, and AT). In total, 31 skinks were sighted corresponding to at least 20 different individuals (Lorvelec et al., 2016; Fig. 3C-D). The dry stone wall on which we made most sightings, i.e., 15 reports corresponding to at least 9 different individuals, was the same as on the previous visit (M2). This survey also allowed collecting and preserving two whole specimens, which were deposited in the Museum National d'Histoire Naturelle of Paris. Also in November 2014, OL, NB, and AT, accompanied by two other people, spent two and a half days looking carefully for skinks on the French side of St. Martin. The surveying sites were two trails (Sentier des Froussards and Sentier du Pic Paradis) and dry stone walls on the north of the island (northwest of Anse Marcel and the hill above Grandes Cayes).

Another survey devoted to skinks (three days) was carried out on Tintamarre in December 2014 and com- 
prised a team of three people (including JC and SBH). The three persons observed approximately 10 skinks per day on the same stone walls as in the earlier survey, with most activity on wall M2. It was not possible to determine if they were the same 10 skinks each day, but other walls examined tended not to be productive. This survey also allowed collecting a tail tip. Also in December 2014, SBH and an assistant spent three days surveying stone walls and other habitats for skinks on St. Martin, including the French and Dutch sides. The stone walls examined were similar to those on Tintamarre. The locations surveyed included Little Bay, the type locality of Spondylurus martinae, and Grand Îlet, the large island in the middle of Simpson Bay Lagoon (or Grand Étang de Simsonbay), although no stone walls were found at either place. Other locations surveyed included the stone walls at Loterie Farm, on the north coast east of Baie des Petites Cayes, and on the southern side of Bellevue, as well as a scattering of other suitable locations (shaded, with ground cover) around the island.

Estimation of the population size. To estimate an approximate size of the population, we used the November 2014 data for the two most-studied stone walls (M2 and M3, Fig. 2). Assuming that we were able to identify all of the skinks seen on the same day, and that skinks observed on different days at locations more than $5 \mathrm{~m}$ apart were different individuals, we estimated that fewer than 10 adult skinks live on each of these two walls. Assuming that a comparable number of skinks live on each of the four north-south walls and that the network of shorter west-east walls also support fewer than 10 skinks (we made only one sighting in March 2013 and another in November 2014), we estimate a total population of 40-50 adult individuals for the entire island.

Species identification. Biological material from skinks of the Anguilla Bank allows morphological comparisons between St. Martin (Spondylurus martinae, known by nine old museum specimens), Tintamarre (this document), St. Barts (S. powelli, six specimens), and Anguilla (S. powelli, ten specimens) (Hedges \& Conn 2012). It also allows genetic comparisons between skinks of all these islands, with the exception of historical St. Martin speci-

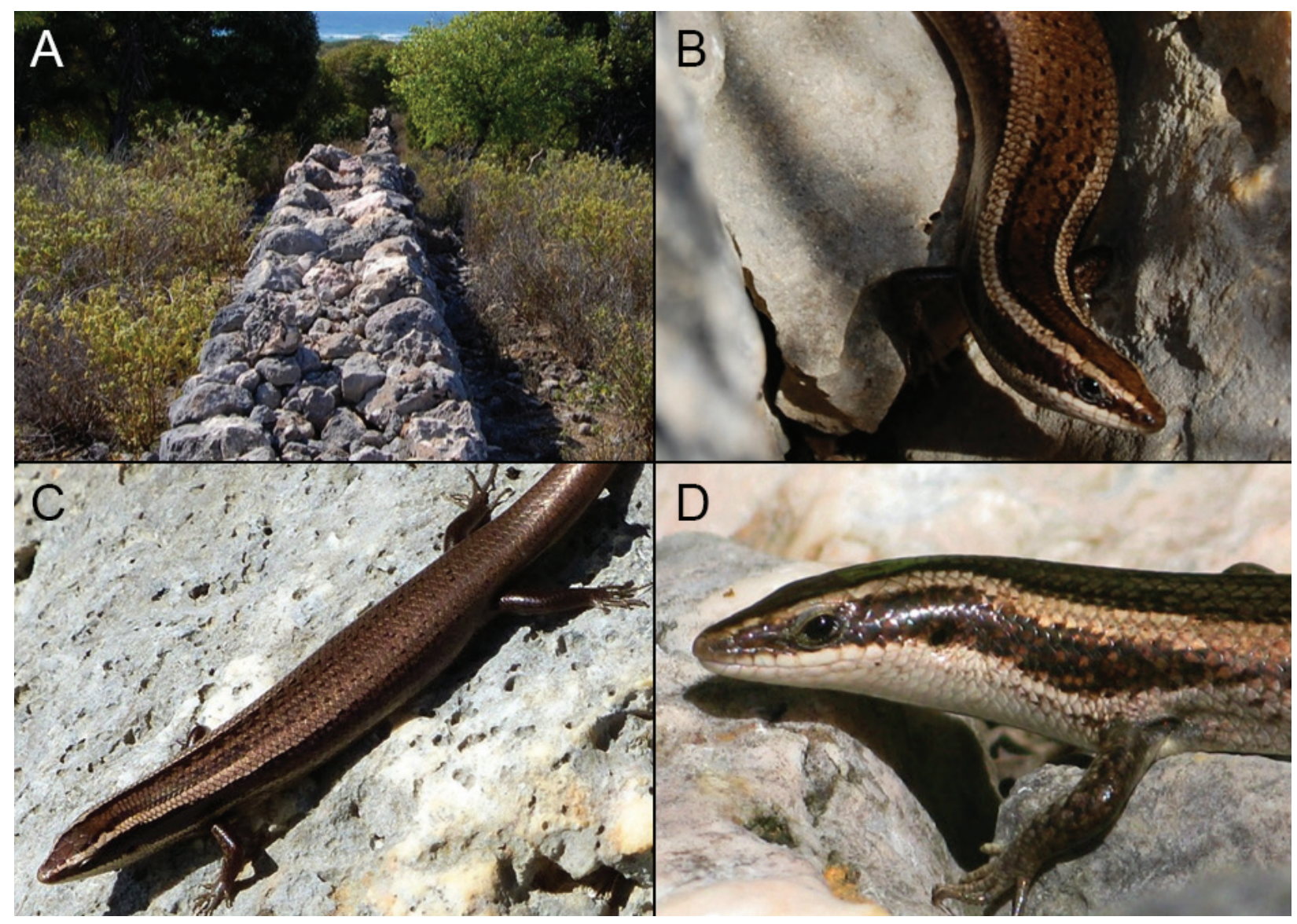

Figure 3. Dry stone wall habitat (A) and live individuals (B-D) of Spondylurus powelli on Tintamarre. 
mens (DNA not sampled).

The DNA sequences of the three samples from Tintamarre are identical to those of Spondylurus powelli from Anguilla (the type locality), with only a single base in cytochrome b showing variation in the three genes ( 3000 sites). The sequences of S. powelli from St. Barts that were obtained from GenBank (collected by other authors) are less complete across the region compared, and they include ambiguous sites. Nonetheless, the St. Barts sequences are also nearly identical to those from the other two islands. These low levels of divergence are typical for individuals in a population or species of Spondylurus (see Hedges \& Conn 2012). For reference, the typical divergence of closely related species in the genus is about 10 times greater ( $1 \%$ at cytochrome b; Hedges \& Conn 2012; Hedges et al. 2016). Therefore, the molecular evidence alone indicates that the Tintamarre skinks are S. powelli.

Likewise, morphological analysis indicates that both whole specimens of Tintamarre are the same species as those of Anguilla and St. Barts (Spondylurus powelli), and not S. martinae of St. Martin. For example, the primary non-overlapping character is ventral scales (Hedges \& Conn 2012): 60 and 63 for the two specimens from Tintamarre, which agrees with S. powelli (range 62-67; mean $=64.1 ; 95 \% \mathrm{Cl} 63.1-65.1 ; \mathrm{n}=16$ ), and not S. martinae (range 68-71; mean=69; 95\% Cl 68.1-69.9; $\mathrm{n}=9$ ). Also, the body size (snout to vent length): 56 and $66 \mathrm{~mm}$ for the two specimens from Tintamarre, agrees with the smaller body size of $S$. powelli (maximum $71.7 \mathrm{~mm}, \mathrm{n}=15$ adults) and not S. martinae (maximum $83.1 \mathrm{~mm} \mathrm{SVL}, \mathrm{n}=4$ adults). Importantly, two of the four known adults of S. martinae are larger ( 72.7 and $83.1 \mathrm{~mm} \mathrm{SVL}$ ) than any of the 17 measured adults (males and females) of S. powelli. In addition, all skinks observed on Tintamarre and not measured (at least 20 different individuals, see above) were within the size range of museum specimens of $S$. powelli, which is also a more attenuate species than the stout-bodied $S$. martinae (e.g., Hedges \& Conn 2012: fig. 71). Therefore, based on DNA and morphology, we conclude that skinks of Tintamarre belong to S. powelli.

\section{Discussion}

Biogeographic issue. On Tintamarre, the presence of a skink population belonging to the species of Anguilla and St. Barts (Spondylurus powelli) and not to the species of St. Martin (S. martinae) may seem surprising, given the geographical closeness of Tintamarre and St. Martin (Fig. 1). However, this case is found in at least one other taxon of squamates. Indeed, Censky \& Paulson (1992) indicated that Tintamarre hosts the nominate form of the Anguilla Bank Ameiva (Pholidoscelis plei plei), which also lives on Anguilla, St. Barts, and several satellites of these islands, and not the subspecies of St. Martin (Pholidoscelis plei analifera). According to Breuil (2002), some individuals from the northeast of St. Martin (opposite Tintamarre) have a pattern of coloration similar to that of the nominative form. With regard to Spondylurus, the difference in the two species (S. martinae and S. powelli) is more substantial, involving scalation and body size, and there is no evidence of any intergradation, although the distribution and variation of S. martinae is poorly known.

The Common Thick-tailed Gecko (Thecadactylus rapicauda) has a wide range, which includes the Anguilla Bank. However, Köhler \& Vesely (2011) described Thecadactylus oskrobapreinorum, the St. Martin Thick-tailed Gecko, known only from St. Martin. Both species of Thecadactylus are present on St. Martin (Yokoyama 2013). They can be differentiated by dorsal patterns. We observed two Thecadactylus in November 2014 on the French side of St. Martin. Both had the pattern of T. oskrobapreinorum. Thecadactylus rapicauda occurs on Anguilla and St. Barts. To our knowledge, neither species has been reported from Tintamarre, but this relatively large island includes suitable habitat. If only $T$. rapicauda is discovered on Tintamarre in the future, it would provide another example of a difference in taxonomic composition between St. Martin and Tintamarre.

Therefore, it seems that Tintamarre harbors a herpetofauna closer to that of remote large islands of the Anguilla Bank (Anguilla and St. Barts located more than 10 and $23 \mathrm{~km}$ away, respectively), than that of St. Martin (less than $3 \mathrm{~km}$ away; Fig. 1). How can we explain this distribution pattern? Currently, islands of the Anguilla Bank 
are separated by seabeds that do not exceed $30 \mathrm{~m}$ in depth, and seabeds between Tintamarre and St. Martin do not exceed $20 \mathrm{~m}$, suggesting a recent separation of some thousands of years. Often, in the case of the Lesser Antillean herpetofauna, species are endemic at a bank level, as shown by the consultation of lists of species by island (e.g., Henderson \& Breuil 2012). Islands belonging to the same bank constituted a single island at the conventional Last Glacial Maximum (between -21,000 and -19,000 years BP). It is commonly recognized that, at this time, overall ocean level was about $120 \mathrm{~m}$ below the current level (e.g., Peltier \& Fairbanks 2006). However, species or subspecies are sometimes endemic to a single island within a bank including several islands. This is the case of the Petite Terre Skink, Mabuya parviterrae, recently described by Hedges et al. (2016), which lives only on Terre de Bas, one of the two islets of Îles de la Petite Terre. Analysis of DNA of this skink showed that it diverged about 500,000 years ago from the Désirade Skink, Mabuya desiradae, described by Hedges \& Conn (2012). However, La Désirade and Îles de la Petite Terre both belong to the Guadeloupe Bank and seabeds separating them do not exceed $20 \mathrm{~m}$ in depth. Hedges et al. (2016) hypothesized the existence of a terrestrial ecological discontinuity between La Désirade and Îles de la Petite Terre, allowing isolation to be maintained between both taxa at the time of the marine regressions linked to the last glacial periods. In the case of the Anguilla Bank, an ecological discontinuity isolating the western part of the bank (i.e., St. Martin) at the time of the last marine regressions could explain current herpetofaunas.

It is possible that there are other populations of skinks on other islets of the Anguilla Bank. Their discoveries would improve our understanding of the biogeography of skinks of this Bank. It should be noted that there is a population of skinks on Dog Island (located west of Anguilla), which has not yet been studied from a taxonomic point of view. Hedges \& Conn (2012) tentatively assigned it to Spondylurus powelli.

Threats and conservation issues. According to Hedges \& Conn (2012), Caribbean skinks were first threatened by the introduction of predatory mammals, especially the Small Indian Mongoose (Urva auropunctata). Secondary threats include habitat destruction from agriculture and urbanization and predation from other introduced mammals, including the Black Rat (Rattus rattus). The conservation status of Spondylurus martinae is listed as Critically Endangered (Possibly Extinct) by the IUCN (Hedges 2016). Based on the IUCN Red List Categories and Criteria (IUCN 2001), Hedges \& Conn (2012) proposed that the conservation status of S. powelli be assessed as Vulnerable, although it is currently being proposed by the IUCN as Endangered (P. Bowles, personal communication).

Trapping operations, carried out in May 2010 and March 2013 by INRA and RNNSM, allowed us to confirm the presence on Tintamarre of two introduced rodents, the Black Rat and the House Mouse (Mus musculus), which had already been sighted by Brown (2008). We do not confirm the presence of the Brown Rat (Rattus norvegicus) also mentioned by this author. Mongooses are absent and a herd of feral goats is present.

The size of the population of Spondylurus powelli of Tintamarre is very limited, estimated here to be 40-50 adult individuals. This number is comparable to that of Mabuya parviterrae, which is endemic to Terre de Bas (Îles de la Petite Terre) in Guadeloupe (Hedges et al. 2016; Lorvelec et al. 2016). The two islands are almost the same size $\left(1.20 \mathrm{~km}^{2}\right.$ for Tintamarre, $1.17 \mathrm{~km}^{2}$ for Terre de Bas). Habitats are similar, including thickets (secondary vegetation formations) and dry forest remnants. In both cases, skinks appear to be limited to dry stone walls, which would seem to offer little protection against rats. Taking into account only the four main walls (north/south), the primary distribution (area of occupancy) of the Tintamarre population of S. powelli is only $2000 \mathrm{~m}^{2}$.

On Tintamarre, the issue related to the conservation of $S$. powelli is made more complicated by the fact that only the coastal zone has the status of a nature reserve. It will therefore be necessary to include the private owner of the center of the island, where the skinks occur, in a future conservation program. Protection and maintenance of the small dry stone walls, which are in a better state than those of Terre de Bas (Îles de la Petite Terre), as well as the control of black rats (preferably eradication and at least limitation) would be favorable to skinks. Above all, an immediate response must occur if mongooses are found on the island and development should be avoided to the greatest extent possible.

Although no skinks were observed at any location on St. Martin during these three short surveys, ad- 
ditional efforts of greater intensity are needed before the extinction of Spondylurus martinae can be confirmed. The fact that two specimens were collected in the early 1960's, approximately 75 years after the mongoose was introduced to St. Martin (circa 1885 according to Husson 1960), indicates that it did not become extinct quickly and may still exist in small populations.

\section{Acknowledgements}

The field work was conducted under the scope of a project to study the conservation of skinks of the French Antilles, hosted since 2012 by the "Association pour l'Étude et la protection des Vertébrés et végétaux des petites Antilles" (AEVA). We thank the "Direction de l'Environnement, de l'Aménagement et du Logement de la Guadeloupe" (DEAL), especially Luc Legendre, for funding, particularly the November 2014 survey trip, authorization for three of us ( $\mathrm{OL}, \mathrm{NB}$, and $\mathrm{SBH}$ ) to collect biological material of a protected species in the territory of St. Martin, and authorization to transport that material to the USA. We thank the conservators of the RNNSM, Romain Renoux and Nicolas Maslach, for co-funding with DEAL the March 2013 survey trip, and authorization for working and sampling in the reserve. The December 2014 survey trip and the genetic analyses were supported by the Center for Biodiversity (CB) at Temple University. We thank Allison Loveless (CB) for sequencing the genetic samples and Tonia Hsieh (CB) for assisting in the fieldwork on that trip and for commenting on the manuscript. We thank RNNSM for maritime logistics. We are grateful to all members of RNNSM, Aurélien Schmitt (student volunteer who observed the first skink on Tintamarre on 8 March 2013), Patricia Le Quilliec (INRA ESE), and volunteers (AEVA, CL, and students), for their participation in fieldwork. We thank Damien Fourcy (INRA ESE) for the map of the Anguilla Bank. Finally, we thank Mike Bolton, who helped translate an early version of this manuscript from French to English.

\section{References}

Breuil M (2002) Histoire naturelle des amphibiens et reptiles terrestres de l'Archipel Guadeloupéen. Guadeloupe, Saint-Martin, Saint-Barthélemy. Patrimoines naturels, 54, 1-339.

Brown AC (2008) Status and range of introduced mammals on St. Martin, Lesser Antilles. Living World (Journal of the Trinidad and Tobago Field Naturalists' Club), 2008, 14-18.

Censky EJ, Paulson DR (1992) Revision of the Ameiva (Reptilia: Teiidae) of the Anguilla Bank, West Indies. Annals of the Carnegie Museum, 61(3), 177-195.

Hedges SB (2016) Spondylurus martinae. The IUCN Red List of Threatened Species. Available from http://www.iucnredlist.org. Accessed 21 April 2017.

Hedges SB, Conn C (2012) A new skink fauna from Caribbean Islands (Squamata, Mabuyidae, Mabuyinae). Zootaxa, $3288,1-244$.

Hedges SB, Lorvelec O, Barré N, Berchel J, Diard Combot M, Vidal N, Pavis C (2016) A new species of skink from the Guadeloupe Archipelago (Squamata, Mabuyidae, Mabuya). Caribbean Herpetology, 53, 1-14.

Henderson RW, Breuil M (2012) Lesser Antilles, pages 148-159. In: Island lists of West Indian amphibians and reptiles, Powell R, Henderson RW, editors, Bulletin of the Florida Museum of Natural History, 51, 85-166.

Husson AM (1960) De Zoogdieren van de Nederlandse Antillen. Mammals of the Netherlands Antilles. Natuurwetenschappelijke Werkgroep Nederlandse Antillen, Curaçao, West Indies.

IUCN (2001) IUCN Red List Categories and Criteria: Version 3.1. IUCN Species Survival Commission. IUCN, Gland, Switzerland and Cambridge, UK. Available from http://www.iucnredlist.org. Accessed 21 April 2017.

Köhler G, Vesely M (2011) A new species of Thecadactylus from Sint Maarten, Lesser Antilles (Reptilia, Squamata, Gekkonidae). ZooKeys, 118, 97-107.

Lorvelec O (2011) Mabuya mabouya (Lesser Antillean Skink). Conservation. Caribbean Herpetology, 19, 1.

Lorvelec O, Barré N, Pavis C (2012) Les dernières populations de scinques dans les Antilles françaises: état des connaissances et propositions d'actions. Report AEVA n³5. Association pour l'Étude et la protection des Vertébrés 
et végétaux des petites Antilles (AEVA), Petit-Bourg, Guadeloupe, France.

Lorvelec O, Barré N, Pavis C (2016) Étude des populations de scinques des Antilles françaises et propositions de gestion. Années : 2012-2016. Report AEVA n41. Association pour l'Étude et la protection des Vertébrés et végétaux des petites Antilles (AEVA), Petit-Bourg, Guadeloupe, France.

Lorvelec O, Pisanu B, Schmitt A, Vallon T (2013) Spondylurus martinae (Saint Martin Skink). Distribution. Caribbean Herpetology, 39, 1.

Métaireau P, Barré N, Lorvelec O, Diard M, Pavis C (2014) Inventaire et cartographie de la population du scinque Mabuya desiradae dans les espaces naturels de la Désirade (Guadeloupe). Année 2014. Report AEVA n³7. Association pour l'Étude et la protection des Vertébrés et végétaux des petites Antilles (AEVA), Petit-Bourg, Guadeloupe, France.

Peltier WR, Fairbanks RG (2006) Global glacial ice volume and Last Glacial Maximum duration from an extended Barbados sea level record. Quaternary Science Reviews, 25, 3322-3337.

Powell R, Henderson RW, Parmerlee JS Jr (2015) The reptiles and amphibians of the Dutch Caribbean: Saba, St. Eustatius, and St. Maarten. Second edition, revised and expanded. Nature Guide Series No. 004. Dutch Caribbean Nature Alliance, Kralendijk, Bonaire.

Schedwill P, Barré N, Lorvelec O, Diard M, Pavis C (2014) Étude de la population du scinque Mabuya cf. desiradae de Terre de Bas (îles de la Petite Terre, commune de la Désirade, Guadeloupe). Années 2012 et 2013. Report AEVA $n^{\circ} 36$. Association pour l'Étude et la protection des Vertébrés et végétaux des petites Antilles (AEVA), Petit-Bourg, Guadeloupe, France.

Yokoyama M (2013) The incomplete guide to the wildlife of Saint Martin, second edition. Mark Yokoyama, Saint Martin. 